J. Product. \& Dev., 19(3):263 - 286 (2014)

\title{
RESPONSE OF Ocimum basilicum PLANT TO SOME PLANT GROWTH PROMOTING RHIZOBACTERIA
}

\author{
Abeer H. Kassem ${ }^{* * *}$, Abou-Zeid M.Y." and Heba Sh. Shehata* \\ *Soil, Water and Environment Research Institute and ${ }^{* *}$ Horticulture \\ Research Institute, Agricultural Research Centre, Cairo, Egypt.
}

\begin{abstract}
Two field experiments were conducted during the two successive growing seasons of 2011 and 2012 to evaluate the effect of ten inoculation treatments with mixtures of some plant growth promoting rhizobacteria (PGPR); i.e., Paenibacillus polymyxa (P), Azospirillum brasilense $(A)$ and some isolates of growth promoting rhizobacteria; i.e., Pseudomonas synxantha (P1) and Bacillus subtilis 2 (B2) on Ocimum basilicum plant growth and herb yield, and to assess to what extant inoculation treatments reduce the demand of basil plant to nitrogen chemical fertilization. Inoculated plants were received only $75 \%$ of the recommended $N$ fertilizer dose (45 kg N/ fad), while control plants were received $100 \%$ of the recommended $N$ fertilizer dose $160 \mathrm{~kg}$ $N /$ fad) without PGPR inoculation.
\end{abstract}

Results indicated that inoculation basil plants with bacterial inoculants mixture containing $(A+P 1+B 2)$ or $(A+P 1)$ under the effect of $75 \% N$ dose resulted in the tallest plants bearing the highest number of branches/ plant and increased herb fresh and dry weights/ plant and/ fad comparing to control plants and all other inoculation treatments. Also, plants treated with these two the abovementioned inoculation treatments resulted in essential oil \%, essential oil yield/ plant and/ fad statistically exceed or equal to that produced from control plants.

Respecting essential oil components, $75 \% \mathrm{~N}+(A+P 1)$ treatment increased $\beta$-pinene and camphor percentages, while $75 \% \mathrm{~N}+(\mathrm{A}+$ $P 1+B 2)$ treatment increased linalool \% comparing to their percentages in oil extracted from control plants. In addition, Methyl-chavicol \%, which is described as a carcinogen and limits the application of basil oil in therapy, was decreased under the effect of these two treatments.

The caused improvement in plant growth, herb yield and essential oil yield and its properties in plants received $75 \% N$ and inoculated with inoculant mixture containing $(A+P 1)$ or $(A+P 1+B 2)$ was associated with increases in percentages of total carbohydrates, $N, P$ and $K$ in their tissues. Also, inoculation with all PGPR under this study significantly reduced dehydrogenase enzyme activity, but significantly increased 
nitrogenase enzyme activity in the soil rhisosphere of inoculated basil plants.

Conclusively, it could be conclude that inoculation of Ocimum basilicum plant with inoculant bacterial mixture containing equal portions of (Azospirillum brasilense + Pseudomonas synxantha) or (Azospirillum brasilense+ Pseudomonas synxantha + Bacillus subtilis 2) can be compensate the demand of nitrogen mineral fertilization and can improve plant growth, herb yield, essential oil yield and medicinal properties of herb and its essential oil as compare to herb and oil of $100 \%$ N fertilized plants without PGPR inoculation.

Key words: Basil, growth, essential oil, nutrient uptake, PGPR, Pseudomonas sp, Bacillus subtitles, Paenibacillus polymyxa, Azospirillum brasilense.

\section{INTRODUCTION}

Nowadays, medicinal and aromatic plants gained great importance because the safety and effectiveness of their medicinal components. The world now getting far from chemicals as pollution factors because their harmful effects and turned toward the natural products.

Basil belongs to the genus Ocimum, having strong odor referred to its essential oil (McIntosh, 1953). Basil is a widely grown as aromatic crop cultivated for production of essential oil, dry leaves for fresh market, or as an ornamental plant (Simon et al., 1990). Basil has been used as a folk remedy for an enormous number of ailments including: boredom, cancer, convulsion, deafness, diarrhea, epilepsy, gout, impotency, nausea, sore throat, toothaches, and whooping cough. Also, basil has been reported in herbal publications as an insect repellent (Duke, 1985). Recently, the potential uses of Ocimum basilicum essential oil as antimicrobial and antioxidant agents have also been investigated (Politeo et al., 2007). Ocimum basilicum essential oil exhibited a wide and varying array of chemical compounds depending on variations in chemo types, leaf and flower colors, aroma and origin of the plant (Sajjadi 2006). It has been reported that the leafy parts of basil have tonic, antiseptic (Kosekia et al., 2002) and insecticidal properties (Umerie et al., 1998). It is also known the leaves of basil are suitable for the treatment of pain (Basilico and Basilico, 1999).

Bio-fertilizers including plant growth promoting rhizobacteria (PGPR) has become a feasible practice. PGPR are root associated bacteria representing many different genera and species that colonize the rhizosphere and improve plant growth. PGPR may improve plant growth and yield by direct and/ or indirect mechanisms (Noel et al., 1996). Indirect mechanisms 
of plant growth stimulation may include variety of mechanisms by which the bacteria prevent phyto-pathogens from inhibiting plant growth and development (Glick and Bashan, 1997). While, direct mechanisms may act on the plant itself and affect growth by providing plants with fixed nitrogen, phyto-hormones, iron and soluble phosphate (Kloepper and Schroth, 1978). Also, PGPR can protect plants against the deleterious effects of some environmental stresses including flooding (Grichko and Glick, 2001), drought (Mayak et al., 2004a), salt (Mayak et al., 2004b) and phytopathogens (Harman and BjÖrkman, 1998). They can increase the availability of nutrients to the host plant, lowering of the ethylene level within the plant and/ or enhance production of stimulatory compounds, such as some plant growth regulators (Phippen and Simon, 1998).

Different PGPR including associative bacteria such as Bacillus, Azospirillum, Pseudomonas and Enterobacter have been used for their beneficial effects on plant growth (Grayer et al., 1996). Many marketable biofertilizers are mainly based on PGPR that exert beneficial effects on plant development often related to the increment of nutrient availability to host plant (Bozin et al., 2006).

Paenibacillus polymyxa, also known as Bacillus polymyxa, is one of the most important and often reported as PGPR (Timmusk et al., 1999) with a wide range of properties including: phosphors solubilization (de Freitas et al., 1997); nitrogen fixation (Coelho et al., 2003); produced cytokinins (Timmusk et al.,1999), antibiotics (Rosado and Seldin, 1993), and hydrolytic enzymes (Nielson and Sorenson, 1997); enhance colonization of hair and cortical cells (Shishido et al., 1999); and increased root and shoot growth of crops (Sudha et al., 1999). According to Ramadan et al. (2007), Bacillus polymyxa produces active products including indole acetic acid and gibberellins as high as 167 and $584 \mathrm{mg} / \mathrm{L}$, respectively. Another effect includes an increase in mobilization of insoluble nutrients followed by enhancement of uptake by the plants (Lifshutz et al., 1987). Moharram et al. (1997) reported that inoculation of wheat with Bacillus polymyxa together with organic or inorganic nitrogen applications increased plant dry weight and $\mathrm{N}_{2}$-fixation. Also, Abou-Zeid et al. (2003) on wheat plant reported that bacterial inoculation with Azospirillum brasilense, Azotobacter chroococcum and Bacillus polymyxa led to significant increases in grain yield, grain protein and 1000 grain weight.

In the last decade, distinct microbial communities have been found in various plant organs such as roots, stem and leaves, flowers as well as fruits and seeds or even during plant development (Okunishi et al., 2005). Many of them have been reported to improve plant growth and health (Hardoim et al., 2008). 
Therefore, such work aimed to evaluate to what extent inoculation of Ocimum basilicum plant with some plant growth promoting rhizobacteria (PGPR) reduce the demand of $\mathrm{N}$ mineral fertilization, and to assess effects of bacterial inoculation on plant growth, volatile oil production and its properties, and some chemical constituents of Ocimum basilicum plant.

\section{MATERIALS AND METHODS}

Presented work was carried out during the two successive growing seasons of 2011 and 2012 at the Experimental Farm of medicinal and Aromatic plants Research section, Agricultural research center, Ministry of Agriculture El Kanater ElKhairia, Egypt to investigate the effect of inoculation with some plant growth promoting rhizobacteria (PGPR) under $75 \%$ of the recommended mineral nitrogen fertilizer dose on growth, volatile oil \% and yield and nutrient uptake of basil cultivar Grandvert.

\section{The used bacterial inoculants:}

Paenibacillus polymyxa which also known Bacillus polymyxa (referred P) and Azospirillum brasilense (referred A) were kindly supplied from Microbiology Dept., Soil, Water and Environment Res. Inst., Agric. Res. Center, Ministry Agric., Giza, Egypt. Also, samples from some rhizosphere of sugar beet, bean and maize plants were collected from different locations of Sahl Eltina and Ismailia. Then, isolation of the rhizosphere bacteria was done; the used method for isolation can be summarized as follows:

Ten grams of rhizosphere soil were suspended in $90 \mathrm{ml}$ of sterilized water in conical flask $(250 \mathrm{ml})$, thoroughly shacked for 10 minutes, and dilution series up to $10^{7}$ were prepared. Dilutions from each soil sample were placed in plates on King's Media (King et al., 1954). Plates were incubated at $28^{\circ} \mathrm{C} \pm 2$ for 1-3 days, and then the individual colonies were picked up, purified and microscopically examined for morphological characteristics. Isolates were maintained on nutrient agar at $4^{\circ} \mathrm{C}$ and subcultures of the purified isolates were done monthly.

Quantitative capability for indole acetic acid (IAA) and gibberellins (GA) production in culture media of Paenibacillus polymyxa (P), Azospirillum brasilense (A) and all rhizobacteria isolates was determined (Table 1). Procedures of Bric et al., (1991) and Udagwa and Kinosheta (1961) were used for IAA and GA determinations, respectively. However, it can be obtained four rhizobacteria isolates. Plant growth promoting substances determinations in culture media of these isolates showed that Pseudomonas synxantha (P1) excreted the maximum amount $(89.2 \mathrm{mg} / \mathrm{l})$ of IAA, while the highest GA production $(358.6 \mathrm{mg} / \mathrm{L})$ was resulted by Bacillus subtilis 2 (B2). So, P1 and 
Table 1: Production of indole acetic acid (IAA) and gibberellins (GA) by used bacterial strains and isolates

\begin{tabular}{|c|c|c|}
\hline \multirow{2}{*}{ Inoculant } & \multicolumn{2}{|c|}{ Growth promoting substance } \\
\hline & IAA & GA \\
\hline \multicolumn{3}{|l|}{ Bacterial strain } \\
\hline Paenibacillus polymyxa (P) & 157.8 & 456.3 \\
\hline Azospirillum brasilense (A) & 101.4 & 604.7 \\
\hline \multicolumn{3}{|l|}{ Rhizobacteria isolate } \\
\hline Pseudomonas fluorescence & 75.33 & 184.20 \\
\hline Pseudomonas synxantha & 89.20 & 247.43 \\
\hline Bacillus subtilis 1 & 22.11 & 224.93 \\
\hline Bacillus subtilis 2 (B2) & 67.70 & 358.60 \\
\hline
\end{tabular}

B2 bacteria were chosen as inoculants to test their effects on basil plant in this study, while the other two isolates; i.e., Pseudomonas fluorescence and Bacillus subtitles 1 were canceled.

\section{Identification of bacterial isolates:}

Active isolates of $\mathrm{P} 1$ and $\mathrm{B} 2$ bacteria which produced more IAA and GA were selected and identified by Bio-log technique in Plant Path. Res. Inst., Agric. Res. Center, Ministry Agric., Giza, Egypt.

\section{The experimental layout:}

Such experiment was implicated 10 treatments. They were set as a simple experiment in a completely randomized block design with three replicates. Each replicate contained 24 plants. The 10 experimental treatments were as follows:

1- Control: plants were received $60 \mathrm{~kg} \mathrm{~N} / \mathrm{fad}(100 \%$ of the mineral recommended Nitrogen fertilizer dose).

2- Plants were received $45 \mathrm{~kg} \mathrm{~N} / \mathrm{fad}$ ( $75 \%$ of the recommended Nitrogen fertilizer dose). It was referred as: $75 \% \mathrm{~N}$ treatment.

3- Plants were inoculated with Paenibacillus polymyxa $(\mathrm{P})$ bacteria and received $45 \mathrm{~kg} \mathrm{~N} / \mathrm{fad}$. It was referred as: $75 \% \mathrm{~N}+(\mathrm{P})$ treatment.

4- Plants were inoculated with mixture containing Paenibacillus polymyxa $(\mathrm{P})$ + Pseudomonas synxantha (P1) bacteria and received $45 \mathrm{~kg} \mathrm{~N} /$ fad. It was referred as: $75 \% \mathrm{~N}+(\mathrm{P}+\mathrm{P} 1)$ treatment.

5- Plants were inoculated with mixture containing Paenibacillus polymyxa $(\mathrm{P})$ + Bacillus subtilis 2 (B2) bacteria and received $45 \mathrm{~kg} \mathrm{~N} /$ fad. It was referred as: $75 \% \mathrm{~N}+(\mathrm{P}+\mathrm{B} 2)$ treatment. 
6- Plants were inoculated with mixture containing Paenibacillus polymyxa (P) + Pseudomonas synxantha $(\mathrm{P} 1)+$ Bacillus subtilis 2 (B2) bacteria and received $45 \mathrm{~kg} \mathrm{~N} /$ fad. It was referred as: $75 \% \mathrm{~N}+(\mathrm{P}+\mathrm{P} 1+\mathrm{B} 2)$ treatment.

7- Plants were inoculated with Azospirillum brasilense (A) and received $45 \mathrm{~kg}$ $\mathrm{N} / \mathrm{fad}$. It was referred as: $75 \% \mathrm{~N}+(\mathrm{A})$ treatment.

8- Plants were inoculated with mixture containing Azospirillum brasilense (A) + Pseudomonas synxantha (P1) bacteria and received $45 \mathrm{~kg} \mathrm{~N} /$ fad. It was referred as: $75 \% \mathrm{~N}+(\mathrm{A}+\mathrm{P} 1)$ treatment.

9- Plants were inoculated with mixture containing Azospirillum brasilense (A) + Bacillus subtilis 2 (B2) bacteria and received $45 \mathrm{~kg} \mathrm{~N} / \mathrm{fad}$. It was referred as: $75 \% \mathrm{~N}+(\mathrm{A}+\mathrm{B} 2)$ treatment.

10- Plants were inoculated with mixture containing Azospirillum brasilense (A) + Pseudomonas synxantha $(\mathrm{P} 1)+$ Bacillus subtilis 2 (B2) bacteria and received $45 \mathrm{~kg} \mathrm{~N} / \mathrm{fad}$. It was referred as: $75 \% \mathrm{~N}+(\mathrm{A}+\mathrm{P} 1+\mathrm{B} 2)$ treatment.

\section{The Experimental procedures}

Sweet basil cultivar Grandvert was used in this study. Seeds were obtained from the Agric. Res. Center, Giza, Egypt. Seeds were sown on $15^{\text {th }}$ February during the two tested seasons of 2011 and 2012 in peat moss medium in nursery beds; germination was occurred during 7-10 days. Two months after sowing for the two tested seasons, when seedling were about $15-17 \mathrm{~cm}$ in height and bearing 6-8 leaves, they were transplanted in plots (1.8 X $2.4 \mathrm{~m})$, each had 3 rows with distance of $60 \mathrm{~cm}$ between rows and $30 \mathrm{~cm}$ between plants within the row, 8 plants/ row. Chemical properties of the used experimental soil are shown in Table 2 .

Table 2: Chemical properties of the experimental soil

\begin{tabular}{|c|c|c|c|c|c|c|c|c|c|c|c|c|c|}
\hline \multirow{2}{*}{ 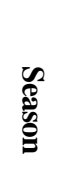 } & \multirow{2}{*}{.S.S } & \multirow{2}{*}{$\mathbf{H}$} & \multirow{2}{*}{$\Xi \stackrel{\stackrel{0}{3}}{3}$} & \multicolumn{4}{|c|}{$\begin{array}{c}\text { Anions } \\
\text { (mg/ } 100 \text { g soil) }\end{array}$} & \multicolumn{4}{|c|}{$\begin{array}{c}\text { Cations } \\
\text { (mg/ } 100 \text { soil) }\end{array}$} & \multicolumn{2}{|c|}{ Ppm } \\
\hline & & & & $\mathbf{O}_{3}$ & $\mathrm{CO}_{3}$ & 1 & $\mathbf{0}_{4}$ & $\mathbf{a}^{++}$ & $\mathrm{g}^{++}$ & $\mathbf{a}^{+}$ & + & & \\
\hline 011 & 0.128 & 7.3 & 0.44 & 01 & .65 & .67 & .88 & .86 & .46 & .48 & .81 & 2.0 & 2.5 \\
\hline 012 & 0.200 & 7.8 & 0.65 & & .78 & .85 & .70 & .23 & .83 & .21 & .93 & 8.0 & 2.8 \\
\hline
\end{tabular}

\section{Fertilization treatments}

Ammonium sulfate $(20.5 \% \mathrm{~N})$ was used as a source of nitrogen fertilization. Plants were received the calculated $\mathrm{N}$ amount according to the treatment; i.e., 60 or $45 \mathrm{~kg} \mathrm{~N} / \mathrm{fad}$ (100\% or $75 \%$ of the recommended $\mathrm{N}$ fertilizer dose, respectively) in two equal portions, the first was on 30 days after transplanting and the second portion was 20 days after the first one. 
Additionally, all of the experimental plots were received phosphorus and potassium fertilization for encourage plant growth. Phosphorus fertilizer in the form of superphosphate $\left(15.5 \% \mathrm{P}_{2} \mathrm{O}_{5}\right)$ at a rate of $100 \mathrm{~kg} / \mathrm{fad}$ was incorporated with the experimental soil of all plots during preparation, while potassium fertilizer was added in the form of potassium sulfate $(48 \% \mathrm{~K} 2 \mathrm{O})$ at the rate of $150 \mathrm{~kg} / \mathrm{fad}$ equally to all experimental plots before the first irrigation.

\section{Inoculation treatments}

The tested bacterial inoculants (bacterial strains and isolated bacteria)

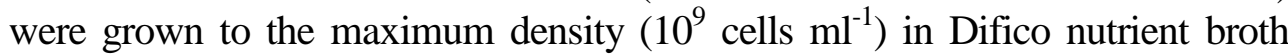
medium (Difico Manual, 1984) for $24 h$. Then, basil seeds were inoculated just before planting by dipping the seeds in bacterial cultures according to the designed treatments; each seed was received about $10^{6}$ cells $\mathrm{ml}^{-1}$. Arabic Gum was used as adhesive agent. Seeds were left overnight for air drying before sowing in the nursery beds. After transplanting, plants were subjected to additional inoculation doses by spraying the bacterial inoculant suspensions, according to the designed treatments, thrice at 30,60 and 90 days from transplanting. Each $100 \mathrm{ml}$ of bacterial culture $\left(10^{9}\right.$ cells $\left.\mathrm{ml}^{-1}\right)$ was diluted with tap water up to 1 liter for preparing the bacterial suspensions for spray. In designed treatments that plants inoculated with more than one bacterial inoculant, the inoculant cultures were well mixed in equal portions just prior to use them in inoculation.

\section{Data recorded}

Growing basil plants were harvested two times by cutting the vegetative parts $10-15 \mathrm{~cm}$ above the soil surface. The first cut was done on $15^{\text {th }}$ June while the second one was on $30^{\text {th }}$ July during the two tested seasons. Response of basil plants to the tested bacterial inoculations were noticed at the two cuts by recording the following data:

\section{Vegetative growth:}

Vegetative growth responses were recorded as plant height $(\mathrm{cm})$, branches number/ plant, and herb fresh and dry weights per plant (g) and per Faddan (ton).

\section{Essential oil determinations:}

Essential oil percentage was determined in fresh herb at two cuts of the two tested seasons according to the method described by British Pharmacopoeia (1963), then oil yield/ plant (ml) and/ Faddan (L) were calculated. In addition, essential oil samples of the $2^{\text {nd }}$ cut during the $2^{\text {nd }}$ season were subjected to GLC for constituents as percentages according to the methods of Hoftman (1967) and Bunzen et al. (1969). 


\section{Chemical analysis:}

Random leaf samples were taken for the two cuts in both experimental seasons and were dried at $70{ }^{\circ} \mathrm{C}$ for 72 hours to determine the leaves chemical constituents. Total nitrogen was determined using semi-micro Kieldahl method which described by Black et al. (1965), total phosphorus was determined using spectrophotometer according to methods of Jackson (1973) and K was determined by using flame photometer according to Yamagnchi and Minges (1956). Also, total carbohydrates were estimated using the method described by Michel et al., (1956). Generally, all N, P and K nutrients as well as total carbohydrate contents were determined as percentages in dry weight.

\section{Rhizosphere enzyme activities}

Activity of Nitrogenase ( $\mathrm{N}_{2}$-ase) and dehydrogenase (DHA) enzymes were estimated in the basil rhizosphere soil at $1^{\text {st }}$ and $2^{\text {nd }}$ cuts for the two tested seasons. $\mathrm{N}_{2}$-ase enzyme activity in $\mathrm{n}$ mole $\mathrm{C}_{2} \mathrm{H}_{4} / \mathrm{g}$ dry rhizosphere soil/ $\mathrm{h}$ was determined using acetylene reduction assay (Hardy et al., 1973). While, DHA enzyme activity in rhizosphere soil, in $\mu \mathrm{g} \mathrm{TPF} / \mathrm{g}$ dry soil /day, was also determined using the method described by Thalmann (1967).

\section{Statistical Analysis}

Recorded data were subjected to statistical analysis and means separation was performed using the least signification difference (LSD) test at 5\% level as described by little and hills (1978).

\section{RESULTS AND DISCUSSION}

\section{Effect of some plant growth promoting rhizobacteria:}

\section{Vegetative growth:}

Basil plants received $75 \%$ of the recommended $\mathrm{N}$ fertilizer dose $(45 \mathrm{Kg}$ $\mathrm{N} / f a d)$ and inoculated with bacterial inoculants mixture containing Azospirillum brasilense + Pseudomonas synxantha + Bacillus subtitles 2 or Azospirillum brasilense + Pseudomonas synxantha $[75 \% \mathrm{~N}+(\mathrm{A}+\mathrm{P} 1+\mathrm{B} 2)$ treatment or $75 \% \mathrm{~N}+(\mathrm{A}+\mathrm{P} 1)$ treatment] resulted in the tallest plants bearing the highest number of branches/ plant comparing to all other inoculation treatments (Table 3). These increments were significant as compare to plants received $100 \%$ of the recommended $\mathrm{N}$ fertilizer $(60 \mathrm{Kg} \mathrm{N} / \mathrm{fad})$ without bacterial inoculation (control). However, $75 \% \mathrm{~N}+(\mathrm{A}+\mathrm{P} 1+\mathrm{B} 2)$ treatment was the superior in this respect. All other inoculation treatments under $75 \% \mathrm{~N}$ fertilizer did not exceed the control treatment, also fertilized plants with $75 \% \mathrm{~N}$ and uninoculated resulted in the shortest plants with the least number of branches/ 
Table 3: Effect of the some plant growth promoting rhizobacteria (PGPR) on plant height and branches number of basil plant

\begin{tabular}{|c|c|c|c|c|c|}
\hline \multicolumn{2}{|c|}{ Treatments } & \multicolumn{2}{|c|}{$\begin{array}{l}\text { Plant height } \\
\text { (cm) }\end{array}$} & \multicolumn{2}{|c|}{$\begin{array}{c}\text { Branches } \\
\text { number/ plant }\end{array}$} \\
\hline $\begin{array}{c}\mathrm{N} \\
\text { fertilization }\end{array}$ & $\begin{array}{l}\text { Xacterial } \\
\text { inoculant }\end{array}$ & $1^{\text {st }}$ cut & $2^{\text {nd }}$ cut & $1^{\text {st }}$ cut & $2^{\text {nd }}$ cut \\
\hline & \multicolumn{5}{|c|}{ Season 2011} \\
\hline 60 & Without & 56.3 & 50.7 & 14.3 & 18.7 \\
\hline 45 & Without & 33.3 & 30.3 & 10.0 & 12.0 \\
\hline 45 & $\mathbf{P}$ & 42.7 & 40.7 & 10.7 & 13.7 \\
\hline 45 & P1 & 48.7 & 43.7 & 13.0 & 17.0 \\
\hline 45 & B2 & 43.3 & 41.0 & 11.7 & 14.0 \\
\hline 45 & $\mathrm{P}+\mathrm{P} 1+\mathrm{B} 2$ & 52.3 & 50.7 & 14.0 & 17.3 \\
\hline 45 & A & 42.7 & 40.0 & 11.3 & 14.3 \\
\hline 45 & $\mathrm{~A}+\mathrm{P} 1$ & 64.7 & 59.7 & 17.3 & 21.0 \\
\hline 45 & $\mathrm{~A}+\mathrm{B2}$ & 45.7 & 45.0 & 12.0 & 15.3 \\
\hline 45 & $\mathrm{~A}+\mathrm{P} 1+\mathrm{B} 2$ & 68.7 & 66.3 & 18.3 & 27.0 \\
\hline LSD 0.05 & & 2.62 & 3.51 & 1.03 & 2.01 \\
\hline & \multicolumn{5}{|c|}{ Season 2012} \\
\hline 60 & Without & 49.7 & 48.3 & 13.0 & 16.7 \\
\hline 45 & Without & 30.0 & 28.7 & 8.00 & 10.7 \\
\hline 45 & $\mathbf{P}$ & 38.3 & 38.7 & 8.67 & 11.0 \\
\hline 45 & P1 & 46.7 & 42.7 & 11.7 & 14.3 \\
\hline 45 & B2 & 39.0 & 39.0 & 9.67 & 12.0 \\
\hline 45 & $\mathrm{P}+\mathrm{P} 1+\mathrm{B} 2$ & 49.0 & 47.0 & 12.0 & 15.0 \\
\hline 45 & $\mathbf{A}$ & 40.7 & 39.3 & 11.0 & 12.7 \\
\hline 45 & $\mathrm{~A}+\mathrm{P1}$ & 61.0 & 58.0 & 14.3 & 19.3 \\
\hline 45 & $\mathrm{~A}+\mathrm{B2}$ & 44.0 & 42.3 & 11.3 & 13.3 \\
\hline 45 & $\mathrm{~A}+\mathrm{P} 1+\mathrm{B} 2$ & 65.0 & 63.0 & 16.7 & 23.0 \\
\hline LSD 0.05 & & 1.77 & 2.62 & 1.00 & 1.11 \\
\hline
\end{tabular}

$60 \mathrm{~kg} \mathrm{~N} / \mathrm{fad}=$ the recommended $\mathrm{N}$ fertilizer dose as control and $45 \mathrm{~kg} \mathrm{~N} / \mathrm{fad}=75 \%$ of the recommended $\mathrm{N}$ fertilizer dose.

${ }^{*} \mathrm{P}=$ Paenibacillus polymyxa, $\mathrm{P} 1=$ Pseudomonas synxantha, $\mathrm{B} 2=$ Bacillus subtitles 2 and $\mathrm{A}=$ Azospirillum brasilense.

plant. Such results were confirmed during the two cuts of the two tested seasons.

Regarding herb fresh and dry weights (Table 4), the noticed increments in plant height and branching of treated plants with $75 \% \mathrm{~N}+(\mathrm{A}+\mathrm{P} 1+\mathrm{B} 2)$ or $75 \%$ $\mathrm{N}+(\mathrm{A}+\mathrm{P} 1)$ treatments were, generally, reflected as significant increases in herb fresh and dry weights/ plant and/ $\mathrm{fad}$ as compare to other inoculation treatments or to fertilized plants with $100 \% \mathrm{~N}$ (control). This was true during the two cuts of the two tested seasons. 
These results are in harmony with those obtained by Abou-Zeid (2011) on soybean and Awad alla et al (2013) on coriander. The obtained results in uninoculated plants were acceptable even they were lower than the other inoculated plants, this behavior may be due to the positive role of plant growth promoting rhizobacteria (PGPR). The increments in plant growth under the effect of inoculation with mixtures of more than one PGPR $[(\mathrm{A}+\mathrm{P} 1+\mathrm{B} 2)$ or $(\mathrm{A}+\mathrm{P} 1)]$ may be attributed to the vital role of such bacteria in production and accumulation of IAA and gibberellins in the plant rhizosphere, as previously mentioned in this research (Table 1). However, according to Galic (1995) and Antoun et al., (1998), PGPR may be improving plant growth and increase yield productivity through different mechanisms including:

1- Production of secondary metabolites such as antibiotic, hydrogen cyanide and plant hormones like substances.

2- The production of siderophors.

3-Antagonism to soil borne root pathogens,

4- Phosphate solubilization and/ or 5- dinitrogen fixation.

As for N fertilizer effect, Sifola and Barbieri (2006) reported that an increase in the rate of applied nitrogen up to $300 \mathrm{~kg} / \mathrm{ha}$ contributed to a rise in the above-ground yield and fresh leaf biomass of basil plant.

\section{Essential oil determinations:}

\section{Essential oil percentage and yield}

Results in Table 5 show significant reductions in essential oil \% in herb of plants received $75 \% \mathrm{~N}$ fertilizer dose without PGPR inoculation comparing to control plants which received $100 \%$ of $\mathrm{N}$ recommended dose. Also, data of the same Table 5, exhibit that all inoculation treatments with different tested PGPR under $75 \% \mathrm{~N}$ did not compensate the caused reduction in oil $\%$, with exception of the triple inoculation treatment of $\mathrm{A}+\mathrm{P} 1+\mathrm{B} 2$ under $75 \% \mathrm{~N}$ or the dual inoculation treatment of A + P1 under $75 \%$ N. Since, plants treated with these two inoculation treatments resulted oil \% statistically exceed or equal to that in plants fertilized with $100 \% \mathrm{~N}$ fertilizer. This was confirmed in the two cuts of the two tested seasons.

As for essential oil yield/ plant and/ fad (Table 5) the same previously mentioned trend in oil \% was repeated in oil yield. Since, triple inoculation treatment of $\mathrm{A}+\mathrm{P} 1+\mathrm{B} 2$ under $75 \% \mathrm{~N}$, generally, resulted significant increases in oil yield/ plant and/ fad. While, dual inoculation treatment of $\mathrm{A}+$ P1 under $75 \%$, generally, resulted in oil yield/ plant and/ fad equal to as in fertilized plants with $100 \% \mathrm{~N}$. However, the increases in oil yield under these two inoculation treatments were expected as a result of the caused increases in oil percentages and in plant growth and herb yield/ plant and / fad under these inoculation treatments (Tables 3\&4). 
Table 5: Effect of some plant growth promoting rhizobacteria (PGPR) on essential oil \% and essential oil yield per plant and per fad of basil plant during 2011 and 2012 seasons

\begin{tabular}{|c|c|c|c|c|c|c|c|}
\hline \multicolumn{2}{|c|}{ Treatments } & \multicolumn{2}{|c|}{$\begin{array}{c}\text { Essential oil } \\
(\%)\end{array}$} & \multicolumn{2}{|c|}{$\begin{array}{c}\text { Essential oil } \\
\text { yield/ plant }(\mathrm{ml})\end{array}$} & \multicolumn{2}{|c|}{$\begin{array}{l}\text { Essential oil } \\
\text { yield/ fad (L) }\end{array}$} \\
\hline $\begin{array}{c}\mathbf{N} \\
\text { fertilization }\end{array}$ & $\begin{array}{c}\text { Bacterial }_{\text {inoculant }} \\
\text { inoula }\end{array}$ & $\begin{array}{l}1^{\text {st }} \\
\text { cut }\end{array}$ & $\begin{array}{l}2^{\text {nd }} \\
\text { cut }\end{array}$ & $\begin{array}{c}1^{\text {st }} \\
\text { Cut }\end{array}$ & $\begin{array}{l}2^{\text {nd }} \\
\text { Cut }\end{array}$ & $\begin{array}{l}1^{\text {st }} \\
\text { Cut }\end{array}$ & $\begin{array}{l}2^{\text {nd }} \\
\text { cut }\end{array}$ \\
\hline \multicolumn{8}{|c|}{ Season 2011} \\
\hline 60 & Without & 0.293 & 0.313 & 0.592 & 0.705 & 14.2 & 16.9 \\
\hline 45 & Without & 0.193 & 0.207 & 0.196 & 0.241 & 4.71 & 5.78 \\
\hline 45 & $\mathbf{P}$ & 0.213 & 0.227 & 0.220 & 0.295 & 5.29 & 7.07 \\
\hline 45 & P1 & 0.253 & 0.280 & 0.395 & 0.518 & 9.48 & 12.4 \\
\hline 45 & B2 & 0.200 & 0.227 & 0.236 & 0.318 & 5.67 & 7.62 \\
\hline 45 & $\mathbf{P}+\mathbf{P} 1+\mathrm{B} 2$ & 0.267 & 0.300 & 0.460 & 0.575 & 11.1 & 13.8 \\
\hline 45 & $\mathbf{A}$ & 0.227 & 0.240 & 0.274 & 0.348 & 6.58 & 8.34 \\
\hline 45 & $A+P 1$ & 0.327 & 0.340 & 0.703 & 0.781 & 16.9 & 18.8 \\
\hline 45 & $\mathrm{~A}+\mathbf{B 2}$ & 0.233 & 0.253 & 0.297 & 0.393 & 7.14 & 9.43 \\
\hline 45 & $\mathrm{~A}+\mathrm{P} 1+\mathrm{B} 2$ & 0.347 & 0.360 & 0.794 & 0.859 & 19.1 & 20.6 \\
\hline LSD 0.05 & & 0.074 & 0.018 & 0.104 & 0.212 & 2.11 & 3.08 \\
\hline \multicolumn{8}{|c|}{ Season 2012} \\
\hline 60 & Without & 0.280 & 0.307 & 0.520 & 0.636 & 12.5 & 15.3 \\
\hline 45 & Without & 0.167 & 0.187 & 0.154 & 0.210 & 3.69 & 5.05 \\
\hline 45 & $\mathbf{P}$ & 0.187 & 0.207 & 0.181 & 0.236 & 4.34 & 5.67 \\
\hline 45 & P1 & 0.247 & 0.273 & 0.352 & 0.474 & 8.44 & 11.4 \\
\hline 45 & B2 & 0.193 & 0.213 & 0.216 & 0.272 & 5.18 & 6.53 \\
\hline 45 & $\mathrm{P}+\mathrm{P} 1+\mathrm{B} 2$ & 0.260 & 0.293 & 0.412 & 0.527 & 9.88 & 12.6 \\
\hline 45 & $\mathbf{A}$ & 0.207 & 0.227 & 0.233 & 0.294 & 5.58 & 7.06 \\
\hline 45 & $\mathbf{A}+\mathbf{P 1}$ & 0.287 & 0.333 & 0.538 & 0.715 & 12.9 & 17.2 \\
\hline 45 & $\mathrm{~A}+\mathrm{B2}$ & 0.227 & 0.247 & 0.258 & 0.350 & 6.19 & 8.39 \\
\hline 45 & $\mathrm{~A}+\mathrm{P} 1+\mathrm{B} 2$ & 0.313 & 0.347 & 0.690 & 0.795 & 16.6 & 19.1 \\
\hline LSD 0.05 & & 0.052 & 0.193 & 0.087 & 0.208 & 1.64 & 2.53 \\
\hline
\end{tabular}

The results regarding $\mathrm{N}$ effects on essential oil are in accordance with those reported by Sifola and Barbieri (2006) and Nurzynska-Wierdak et al., (2013). They noticed that an increases in nitrogen fertilizer amount up to 300 $\mathrm{kg} h a$ resulted in more accumulation in essential oil in sweet basil herb.

Abd-El Kader and Ghaly (2003) on coriander as well as Badran and Safwat (2004) and Badran et al. (2007) on fennel plants recorded similar results by applying PGPR. Banchio et al. (2008) reported that essential oil yield of Origanum majorana $\mathrm{L}$. was significantly increased by inoculation treatments of P. fluorescence and Bradyrhizobium sp comparing to non-inoculated plants, without alteration in oil composition. 


\section{2-Essential oil components}

Essential oil analysis of the extracted samples from basil plants of different treatments (Table 6) showed that, generally, plants received 75\% N fertilizer resulted essential oil had percentages of main components lesser than that in essential oil of plants received $100 \% \mathrm{~N}$ with exceptions of Geranyl-acetate and Camphore, since they were increased with decreasing N fertilization. Such result clear that there is an indefinite role for $\mathrm{N}$-fertilizer where, increasing $\mathrm{N}$ fertilizer gave high percentages of most essential oil components but, gave low values of Camphor and Geranyl-acetate components.

As for effect of PGPR inoculation on essential oil components, results of the same Table 6 showed that linalool, the main component of basil plant oil, was increased in plants received $75 \% \mathrm{~N}$ by inoculation with $\mathrm{B} 2$ or $\mathrm{A}+$ $\mathrm{P} 1+\mathrm{B} 2$ inoculants comparing to plants treated with $100 \% \mathrm{~N}$ without PGPR inoculation (control). These two inoculation treatments resulted in the highest linalool percentages (39.0 and $37.4 \%$, respectively) comparing to the all other inoculation treatments. The highest camphor percentages $(25.8$ and $33.9 \%$ ) were recorded in oil samples of plants received $75 \% \mathrm{~N}$ under effect of the inoculation treatments of P1 or A.

Methyl chavicol component\% (Table 6), which is described as a probable carcinogen (Kaledin et al. 2009) and limits the application of basil oil in therapy, reached to the maximum value $(5.20 \%)$ in essential oil of plants received $100 \% \mathrm{~N}$-fertilizer, while it decreased by decreasing the $\mathrm{N}$ fertilizer to $75 \%$ under all inoculation treatments. The lowest percentages of Methyl chavicol $(0.388 \%$ or $0.511 \%)$ were recorded in essential oil extracted from plants received $75 \% \mathrm{~N}$ and inoculated with $\mathrm{A}$ or $\mathrm{P}+\mathrm{P} 1+\mathrm{B} 2$ inoculants, respectively. Such result was opposite to that reported by Nurzyńska-Wierdak et al. (2013) on sweet basil; they found that an increase in rate of nitrogen fertilizer caused a decrease in the proportion of methyl chavicol in essential oil.

Respecting the effect of the two inoculation treatments of $75 \%$ $\mathrm{N}+(\mathrm{A}+\mathrm{P} 1)$ and $75 \% \mathrm{~N}+(\mathrm{A}+\mathrm{P} 1+\mathrm{B} 2)$, which enhanced plant growth and increased herb yield and essential oil $\%$ and its yield as previously mentioned in this research (Tables 3, 4 and 5), on essential oil components, $75 \% \mathrm{~N}+(\mathrm{A}+\mathrm{P} 1)$ treatment increased $\beta$-Pinene and Camphor percentages, while $75 \% \mathrm{~N}+(\mathrm{A}+\mathrm{p} 1+\mathrm{B} 2)$ increased Linalool\% comparing to their percentages in oil extracted from control plants (Table 6). Also, Methylchavicol \% was decreased under the effect of these two treatments. So, under this study inoculation with some PGPR can increase basil essential production and improve its properties. 
Table 6: Effect of some plant growth promoting rhizobacteria (PGPR) on basil essential oil components $(\%)$ of the $2^{\text {nd }}$ cut during the $2^{\text {nd }}$ season 2012

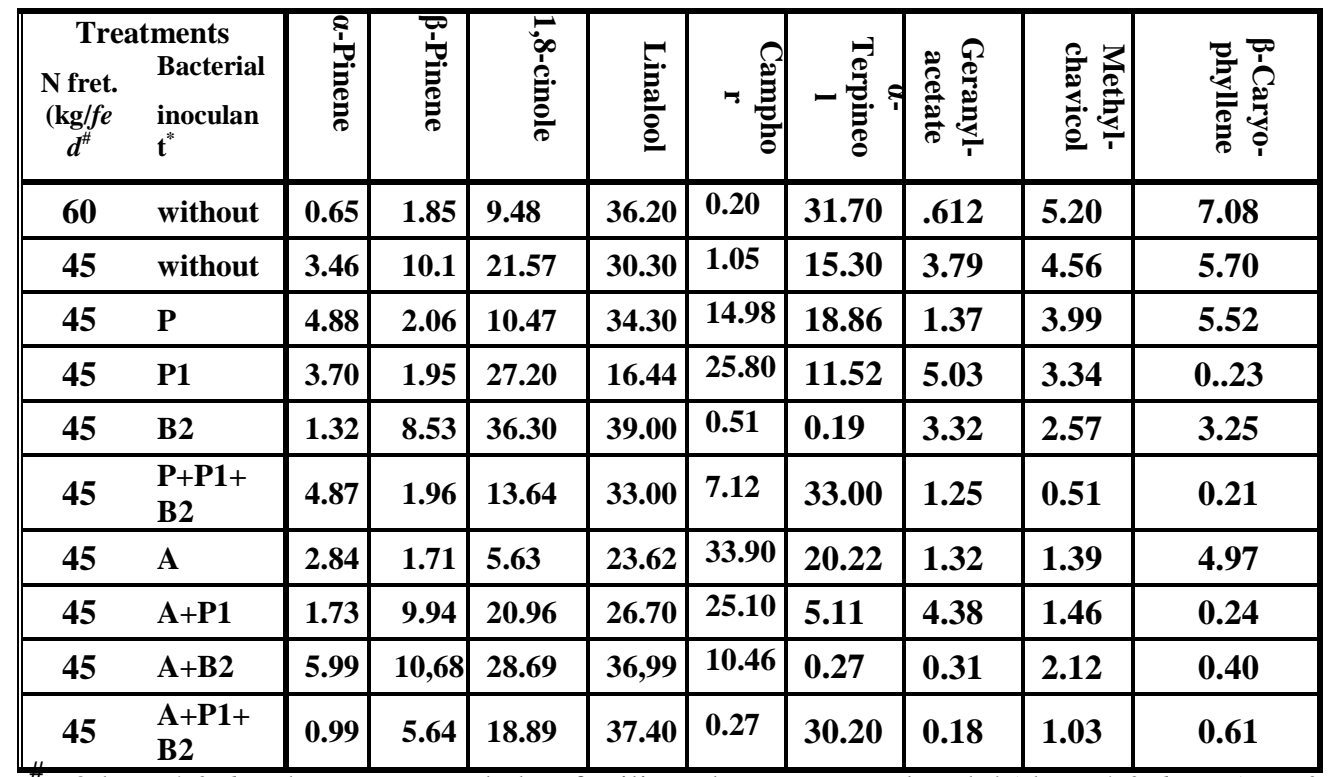

$60 \mathrm{~kg} \mathrm{~N} / \mathrm{fad}=$ the recommended $\mathrm{N}$ fertilizer dose as control and $45 \mathrm{~kg} \mathrm{~N} / \mathrm{fad}=75 \%$ of * the recommended $\mathrm{N}$ fertilizer dose.

* $\mathrm{P}=$ Paenibacillus polymyxa, $\mathrm{P} 1=$ Pseudomonas synxantha, $\mathrm{B} 2=$ Bacillus subtilize 2 and $\mathrm{A}=$ Azospirillum brasilense.

\section{Chemical analysis:}

Data represented chemical analysis (Table 7) clear that reduction $\mathrm{N}$ fertilization level from $100 \%(60 \mathrm{~kg} \mathrm{~N} / \mathrm{fad})$ to $75 \%(45 \mathrm{~kg} \mathrm{~N} / \mathrm{fad})$ of the recommended dose significantly reduced total carbohydrates, N, P and $\mathrm{K}$ percentages in basil leaf tissues. Simultaneously, applying the all tested PGPR inoculation treatments to plants which received the low $\mathrm{N}$ fertilizer level $(75 \% \mathrm{~N})$ resulted in increases in the abovementioned percentages comparing to plants fertilized $75 \% \mathrm{~N}$ without inoculation. The highest increases in total carbohydrates, $\mathrm{N}, \mathrm{P}$ and $\mathrm{K}$ percentages were recorded in fertilized plants with $75 \% \mathrm{~N}$ and inoculated with inoculant mixture containing $(\mathrm{A}+\mathrm{P} 1)$ or $(\mathrm{A}+\mathrm{P} 1+\mathrm{B} 2)$. Such percentages were statistically more than (significant) or equal to (not significant) that in leaf tissues of control plants (fertilized plants with $100 \% \mathrm{~N}$ ). This was confirmed in the two cuts of the two tested seasons.

The increments in total carbohydrates percentage in fertilized plants may be attributed to the structural role of $\mathrm{N}$ in synthesis of porphyrine molecules, which are found in many metabolically active compounds including chlorophylls and cytochrome enzymes. These increases in chlorophylls 
Table 7: Effect of the some plant growth promoting rhizobacteria (PGPR) on basil leaf chemical constituents during the 2011 and 2012 seasons

\begin{tabular}{|c|c|c|c|c|c|c|c|c|c|}
\hline \multicolumn{2}{|c|}{ Treatments } & \multicolumn{2}{|c|}{$\begin{array}{c}\text { Total } \\
\text { carbohydrat } \\
\text { es }(\%)\end{array}$} & \multicolumn{2}{|c|}{$\begin{array}{c}\mathrm{N} \\
(\%)\end{array}$} & \multicolumn{2}{|c|}{$\underset{(\%)}{\mathbf{P}}$} & \multicolumn{2}{|c|}{$\underset{(\%)}{\mathbf{K}}$} \\
\hline $\begin{array}{l}\mathbf{N} \\
\text { fertilizatio } \\
n\end{array}$ & $\begin{array}{l}\text { Bacterial } \\
\text { inoculant }\end{array}$ & $\begin{array}{l}1^{\text {st }} \\
\text { cut }\end{array}$ & $\begin{array}{l}2^{\text {nd }} \\
\text { cut }\end{array}$ & $\begin{array}{l}1^{\text {st }} \\
\text { cut }\end{array}$ & $\begin{array}{l}2^{\text {nd }} \\
\text { cut }\end{array}$ & $\begin{array}{l}1^{\text {st }} \\
\text { cut }\end{array}$ & $\begin{array}{l}2^{\text {nd }} \\
\text { cut }\end{array}$ & $\begin{array}{l}1^{\text {st }} \\
\text { cut }\end{array}$ & $\begin{array}{l}2^{\text {nd }} \\
\text { cut }\end{array}$ \\
\hline & \multicolumn{9}{|c|}{ Season 2011} \\
\hline 60 & Without & 22.1 & 20.6 & 2.58 & 2.8 & 0.37 & 0.43 & 2.2 & 2.7 \\
\hline 45 & Without & 13.2 & 14.3 & 1.68 & 2.1 & 0.22 & 0.23 & 1.2 & 2.0 \\
\hline 45 & $\mathbf{P}$ & 16.8 & 16.1 & 1.93 & 2.4 & 0.31 & 0.31 & 1.6 & 2.2 \\
\hline 45 & P1 & 18.2 & 18.8 & 2.06 & 2.6 & 0.33 & 0.37 & 1.9 & 2.3 \\
\hline 45 & B2 & 17.8 & 17.8 & 2.04 & 2.5 & 0.34 & 0.36 & 1.8 & 2.3 \\
\hline 45 & $\mathbf{P + I}$ & 21.8 & 20.7 & 2.23 & 2.8 & 0.36 & 0.39 & 2.1 & 2.4 \\
\hline 45 & $\mathbf{A}$ & 18.6 & 16.4 & 1.88 & 2.3 & 0.23 & 0.26 & 1.5 & 2.0 \\
\hline 45 & $\mathbf{A}+\mathbf{P 1}$ & 23.8 & 22.7 & 2.63 & 2.8 & 0.38 & 0.45 & 2.3 & 2.7 \\
\hline 45 & $\mathbf{A}+\mathbf{B} 2$ & 16.4 & 17.3 & 2.17 & 2.7 & 0.35 & 0.38 & 2.0 & 2.3 \\
\hline 45 & $A+P 1+B$ & 25.5 & 28.4 & 2.81 & 2.9 & 0.39 & 0.46 & 2.4 & 2.8 \\
\hline LSD 0.05 & & 1.71 & 4.02 & 0.22 & 0.0 & 0.01 & 0.04 & 0.2 & 0.1 \\
\hline \multicolumn{10}{|c|}{ Season 2012} \\
\hline 60 & Without & 22.8 & 23.6 & 2.71 & 2.8 & 0.38 & 0.48 & 2.2 & 2.9 \\
\hline 45 & Without & 13.0 & 14.8 & 1.78 & 2.1 & 0.22 & 0.24 & 1.2 & 2.3 \\
\hline 45 & $\mathbf{P}$ & 15.1 & 16.2 & 1.95 & 2.6 & 0.32 & 0.32 & 1.7 & 2.4 \\
\hline 45 & P1 & 19.5 & 18.8 & 2.18 & 2.7 & 0.34 & 0.38 & 1.9 & 2.5 \\
\hline 45 & B2 & 17.1 & 18.1 & 2.05 & 2.6 & 0.36 & 0.38 & 1.9 & 2.5 \\
\hline 45 & $\mathbf{P}+\mathbf{P} 1+\mathrm{B}$ & 23.6 & 20.1 & 2.84 & 2.8 & 0.37 & 0.40 & 2.3 & 2.6 \\
\hline 45 & $\mathbf{A}$ & 18.5 & 17.1 & 1.87 & 2.2 & 0.34 & 0.28 & 2.2 & 2.2 \\
\hline 45 & $\mathbf{A}+\mathbf{P 1}$ & 25.2 & 28.3 & 2.81 & 2.9 & 0.39 & 0.49 & 2.5 & 2.8 \\
\hline 45 & $\mathrm{~A}+\mathrm{B} 2$ & 18.2 & 17.0 & 2.21 & 2.8 & 0.35 & 0.39 & 2.4 & 2.6 \\
\hline 45 & $\mathrm{~A}+\mathrm{P} 1+\mathrm{B}$ & 26.5 & 28.1 & 2.79 & 2.9 & 0.40 & 0.49 & 2.6 & 2.9 \\
\hline LSD 0.05 & & 1.50 & 1.73 & 0.09 & 0.4 & 0.01 & 0.01 & 0.1 & 0.0 \\
\hline
\end{tabular}

$60 \mathrm{~kg} \mathrm{~N} / \mathrm{fad}=$ the recommended $\mathrm{N}$ fertilizer dose as control and $45 \mathrm{~kg} \mathrm{~N} / \mathrm{fad}=75 \%$ of the recommended $\mathrm{N}$ fertilizer dose.

${ }^{*} \mathrm{P}=$ Paenibacillus polymyxa, $\mathrm{P} 1=$ Pseudomonas synxantha, $\mathrm{B} 2=$ Bacillus subtilis 2 and $\mathrm{A}=$ Azospirillum brasilense.

and cytochrome enzymes might be in turn results in an increase in photosynthesis rate and promote carbohydrates synthesis and accumulation (Devlin, 1975). 
As for PGPR effects on carbohydrates accumulation, Abou-zeid (1993) found that total soluble carbohydrate \% was decreased in inoculated wheat, but increased in rice grain with $A$. brasilense.

Increases $\mathrm{N}, \mathrm{P}$ and $\mathrm{K}$ percentages after PGPR inoculation treatments are in harmony with the results obtained by Fallik et al., (1994) and (Soudi et al., 2008). The enhancing effect of PGPR treatments on $\mathrm{N}, \mathrm{P}$ and $\mathrm{K}$ absorption may be refereed to their influence on increasing the availability of such nutrients via production of plant growth regulators at the root interface, which may stimulate root development and resulted in better absorption of water and nutrients from soil and increased plant growth which enhance the absorption of nutrients from soil (Ordookhani et al., 2010). However, there is some controversy regarding the mechanisms that PGPR employs for uptake of minerals. Many investigators suggested that phytohormones promote uptake of minerals by plant roots due to increase of root surface area, thickness and length (Biswas et al, 2000). Whitelaw et al. (1997) stated that phosphate-solubilizing Bacillus spp stimulates plant growth through enhancing $\mathrm{P}$ absorption.

\section{Rhizosphere enzyme activities}

Nitrogenase enzyme $\left(\mathrm{N}_{2}\right.$-ase) activity in basil rhizosphere in $\mathrm{n}$ mole $\mathrm{C}_{2} \mathrm{H}_{4} / \mathrm{g}$ dry rhisosphere soil / $\mathrm{h}$ and dehydrogenase (DHA) enzyme activity in rhizosphere soil in $\mu \mathrm{g}$ TPF/g dry soil /day in the $1^{\text {st }}$ and $2^{\text {nd }}$ cuts for two tested seasons are presented in Table 8.

With respect to DHA activity, results indicate that the inoculation with all PGPRs under this study significantly reduced DHA enzyme activity, where the maximum values were obtained when plants were fertilized with $75 \%$ of $\mathrm{N}$ without inoculation followed by $100 \% \mathrm{~N}$. Inoculation with Azospirillum $+75 \%$ of $\mathrm{N}$ led to the minimum values of DHA. However, opposite results were found by Zaghloul et al., (2007) on tomato and Abouzeid (2011) on soybean. They stated that seeds inoculation with both of Bacillus polymyxa and Bacillus megatherium led to significant increases in DHA activity in the rhizosphere soil.

Concerning N2-ase activity, data of the same Table 8 indicate that $\mathrm{N}_{2^{-}}$ ase activity was significantly increased by inoculation with the most tested PGPR. The highest values of $\mathrm{N}_{2}$-ase activity were recorded in the rhizosphere soil of plants inoculated with Azospirillum $+75 \% \mathrm{~N}$ in the first season and that inoculated with $\mathrm{P} 1$ under $75 \% \mathrm{~N}$ in the second season. The lowest values of $\mathrm{N}_{2}$-ase activity were found when plants inoculated with $\mathrm{A}$ $+\mathrm{P} 1+\mathrm{B} 2$ with $75 \% \mathrm{~N}$ during the two tested seasons.

Obtained results of uninoculated treatments were acceptable since, they were lower than the other inoculated treatments, this behavior could be 
Table 8: Effect of the some plant growth promoting rhizobacteria (PGPR) on activity of nitrogenase and dehydrogenase enzymes in basil soil rhizosphere during 2011 and 2012 seasons

\begin{tabular}{|c|c|c|c|c|c|}
\hline \multicolumn{2}{|c|}{ Treatments } & \multicolumn{2}{|c|}{$\begin{array}{c}\text { Dehydrogenase enzyme } \\
\text { activity } \\
\text { (n mole } \mathrm{C}_{2} \mathrm{H}_{4} / g \text { dry soil/ } \\
\text { h) }\end{array}$} & \multicolumn{2}{|c|}{$\begin{array}{c}\text { Nitrogenase enzyme } \\
\text { activity } \\
\text { ( } \mu \mathrm{g} \text { TPF/g dry soil/day) }\end{array}$} \\
\hline $\begin{array}{l}\text { Nertilizatio } \\
\text { n kg/ fed }\end{array}$ & $\begin{array}{l}\text { Bacterial } \\
\text { inoculant }\end{array}$ & $\mathbf{1}^{\text {st }} \mathrm{Cut}$ & $2^{\text {nd }} \mathrm{Cut}$ & $1^{\text {st }}$ Cut & $2^{\text {nd }} \mathrm{Cut}$ \\
\hline & \multicolumn{5}{|c|}{ Season 2011} \\
\hline 60 & Without & 163.6 & 243.6 & 55.29 & 21.94 \\
\hline 45 & Without & 217.2 & 262.7 & 34.90 & 43.86 \\
\hline 45 & $\mathbf{P}$ & 55.27 & 116.4 & 79.05 & 48.86 \\
\hline 45 & P1 & 96.35 & 150.4 & 130.87 & 174.64 \\
\hline 45 & B2 & 48.08 & 98.0 & 30.28 & 26.90 \\
\hline 45 & $\mathbf{P}+\mathrm{P} 1+\mathrm{B} 2$ & 74.46 & 124.1 & 18.34 & 54.29 \\
\hline 45 & $\mathbf{A}$ & 46.45 & 67.70 & 434.43 & 55.20 \\
\hline 45 & A+P1 & 72.81 & 100.1 & 198.12 & 51.90 \\
\hline 45 & $\mathbf{A}+\mathbf{B} 2$ & 120.4 & 226.8 & 59.46 & 30.13 \\
\hline 45 & $\mathrm{~A}+\mathrm{P} 1+\mathrm{B} 2$ & 101.9 & 156.8 & 18.86 & 19.87 \\
\hline \multirow[t]{2}{*}{ LSD 0.05} & & 25.74 & 51.29 & 15.01 & 24.46 \\
\hline & \multicolumn{5}{|c|}{ Season 2012} \\
\hline 60 & without & 187.54 & 343.2 & 53.32 & 27.18 \\
\hline 45 & without & 226.89 & 343.0 & 42.12 & 30.91 \\
\hline 45 & $\mathbf{P}$ & 65.45 & 130.1 & 85.10 & 39.81 \\
\hline 45 & P1 & 107.31 & 169.1 & 163.24 & 222.65 \\
\hline 45 & B2 & 92.52 & 126.1 & 28.78 & 21.21 \\
\hline 45 & $\mathbf{P}+\mathbf{P} 1+\mathrm{B} 2$ & 138.32 & 194.5 & 12.46 & 56.47 \\
\hline 45 & A & 45.99 & 73.6 & 210.53 & 71.31 \\
\hline 45 & $\mathbf{A}+\mathbf{P 1}$ & 63.98 & 139.5 & 180.21 & 55.21 \\
\hline 45 & $\mathbf{A}+\mathbf{B} 2$ & 115.53 & 188.2 & 72.32 & 43.51 \\
\hline 45 & $\mathrm{~A}+\mathrm{P} 1+\mathrm{B} 2$ & 121.15 & 176.8 & 22.71 & 28.91 \\
\hline LSD 0.05 & & 26.16 & 26.73 & 21.17 & 15.34 \\
\hline
\end{tabular}

$60 \mathrm{~kg} \mathrm{~N} / \mathrm{fad}=$ the recommended $\mathrm{N}$ fertilizer dose as control and $45 \mathrm{~kg} \mathrm{~N} / \mathrm{fad}=75 \%$ of the recommended $\mathrm{N}$ fertilizer dose.

${ }^{*} \mathrm{P}=$ Paenibacillus polymyxa, $\mathrm{P} 1=$ Pseudomonas synxantha, $\mathrm{B} 2=$ Bacillus subtilis 2 and $\mathrm{A}=$ Azospirillum brasilense.

due to the positive role of native bacteria inhabiting soil among several decades ago (Kloepper and Schorth, 1981), also the presence of active nitrogenase enzyme and DHA enzyme for uninoculated plants is owing to the indigenous bacteria in soil. 
Conclusively, from results of such research, it could be conclude that inoculation of Ocimum basilicum plant with inoculant bacterial mixture containing equal portions of Azospirillum brasilince + Pseudomonas synxantha or Azospirillum brasilince + Pseudomonas synxantha + Bacillus subtilis 2 can be reduce the demand of nitrogen mineral fertilization up to $75 \%$ of the recommended dose $(45 \mathrm{~kg} \mathrm{~N} / \mathrm{fed}$ instead of $60 \mathrm{~kg} \mathrm{~N} / \mathrm{fed}$ ). Since, these two inoculation treatments compensated the mineral $\mathrm{N}$ fertilizer and increased plant growth, herb yield and essential oil yield. Also, inoculation treatments improved medicinal properties of basil herb and its essential oil as compare to herb and oil of $100 \% \mathrm{~N}$ fertilized plants without PGPR inoculation.

\section{REFERENCES}

Abou-Zeid M.Y.; A.R. Al-Kasas and T.E.E. Radwan (2003). Wheat crop production and grain quality in response to nitrogen-fixing bacteria inoculation. Az. J. Pharm. Sci., 31, December, 79-73.

Abou-Zeid, M.Y. (2011): improvement of soybean growth by coinoculation with Rhizobium and plant growth-promoting rhizobacteria. Egypt. J. of Appl. Sci., 26 (11): 445-459

Abou-zeid, M.Y. (1993): Biochemical studies on Azospirillum bacteria in the rhizosphere of some field crop plants. M.Sc. Thesis, Fac. Agric. Ain Shams Univ. Egypt.

Abd-Elkader, H.H. and Ghaly, N.G. (2003): Effect of cutting the herb and the use of nitrobein and phosphorein associated with mineral fertilizers on growth, fruit and oil yield and chemical composition of the essential oil of coriander plants (Coriandrum sativum) J. Agric. Sci. Mansoura Univ., 28 (30), 2161-2171.

Antoun, H.C., J. Beauchamp, N. Houssard, R. Chabat and M. Lolande, 1998. Potential of Rhizobium and Bradyrhizobium species as plant growth promoting rhizobacteria on non-legumes: Effect on radishes (Rophanous sativus, L). Plant and Soil, 204: 762-767.

Awad alla, Salwa S.S.; Ali, Hanan M. H. and Abou-Zeid, M.Y. (2013). Effect of Egyptian Rock Phosphate and Phosphate Dissolving Bacteria on Coriander Plant Growth and Yield. Egypt. J. Hort., Vol. 40:1, 6379.

Badran, F.S. and M.S. Safwat, (2004) Response of Fennel plants to organic manure and biofertilizers in replacement of chemical fertilization Sec. International Conf. of Organic Agric. Cairo, Egypt, March.

Badran, F.S., Nadia M. Abdalla., Ali, M.K. and Soad M. Ibrahim, (2007) Response of fennel plants to seeding rate and partial (replacement 
of mineral NPK by biofertilization treatments. African Crop Sci. Conf. Proc., 8, 417-422.

Banchio, Erika; Bogino, Pablo. C; Zygadlo, Julio and Giordano, Walter (2008). Plant growth promoting rhizobacteria improve growth and essential oil yield in Origanum majorana L. Biochemical Systimatic and Ecology. Volume 36, Issue 10, 766-771

Basilico, M.Z. and J.C. Basilico, 1999. Inhibitory effects of some spice essential oils on Aspergillus ochraceus NRRL 3174 growth and ochratoxin. A production. Lett. Appl. Microbiol., 29: 238-241.

Biswas, J.C. ; J.K. Ladha and F.B. Dazzo (2000). Rhizobia inoculation improves nutrient uptake and growth of lowland rice, Soil Sci. Soc. Am. J., 64: 1644-1650.

Black, C.A.; D.D. Evans; L.E. Ensminger; J.L. White and F.E. Clark (1965). Methods of Soil Analysis. Am. Soc. of Agron. Inc., Madison, Wisconsin, USA.

Bozin, B., N. Mimica-Dukic, N. Simin and G. Anackov, 2006. Characterization of the volatile composition of essential oils of some Lamiaceae spices and the antimicrobial and antioxidant activities of the entire oils. J. Agric. Food Chem., 54: 1822-1828.

Bric, J. M.,R. M. Bostock and S. E. Silverstone (1991). Rapid in situ assay for indole acetic acid production by bacteria $\mathrm{m}$ immobilized on nitrocellulose membrane. Appl. Environ. Microbiol. Biotechnol.,35: 646-650.

British Pharmacopoeia (1963). Determination of Volatile Oils in Drugs. The Pharmaceutical Press, 17 Bloomsbury Square, London, WCL. 220-222.

Bunzen, J.N.; Guichard, J.; Labbe, P.; Prevot, J.; Seprpinet, J. and Tranchant, J. (1969). Practical Manual of Gas Chromatography Journal Tranchant, Ed., El-Seivier Publ. Co., Amesterdam-London 189-206.

Coelho MRR, Weid I, von der Zahner V, Seldin L (2003). Characterization of nitrogen- fixing Paenibacillus species by polymerase chain reaction-restriction fragment length polymorphism analysis of part of genes encoding $16 \mathrm{~S}$ rRNA and 23S rRNA and by multilocus enzyme electrophoresis. FEMS Microbiol Lett, 222:243250

de Freitas J.R., Banerjee M.R., Germida J.J. (1997) Phosphatesolubilizing rhizobacteria enhance the growth and yield but not phosphorus uptake of canola ( Brassica napus L.). Biol Fertil Soils, 24:358-364

Devlin, R.M., 1975. Plant physiology. VanNostrand, New York. 
Difico Manual (1984). Dehydrated Culture Media and Reagents for Microbiology. $10^{\text {th }}$ Ed. Difico Laboratories, Detroit Michigan, 48232. USA, 621.

Duke, James A.(1985): Culinary Herbs: A Potpourri. Buffalo, NY: Bonch Magazine, Limited,

Fallik, E.; S. Sarig and Y. Okon (1994). Morphology and physiology of plant roots associated with Azospirillum. In Azospirillum-Plant Associations, CRC Press, Boca Raton. Edited by Okon Y.77-84.

Galic, C, 1995. The enhancement of plant growth by free-living bacteria. Can. J. Microbiol., 41: 109-117.

Glick, B.R. and Y. Bashan, 1997. Genetic manipulation of plant growthpromoting bacteria to enhance biocontrol of fungal phytopathogens. Biotechnol. Adv. , 15:353-378.

Grayer, R.J., G.C. Kite, F.J. Goldstone, S.E. Bryan, A. Paton and E. Putievsky, 1996. Infraspecific taxonomy and essential oil chemotypes in sweet basil, Ocimum basilicum. Phytochemistry; 43: 1033-1039.

Grichko, V.P., and B.R. Glick, 2001. Amelioration of flooding stress by ACC deaminase-containing plant growth-promoting bacteria. Plant Physiol. Biochem., 39: 11-17.

Hardoim,P. R.;L. S Van Overbeek and J. D. Elsas(2008). Properties of bacteria endophytes and their proposed role in plant growth. Trends in Microbiol., 16: 463-471.

Hardy, R. W. F.; B. C. Bume and R. D. Holsten (1973). Application of the acetylene-ethylene assay for measurement of nitrogen fixation. Soil Biol. Biochem., 5:47-81.

Harman, G.E., and T. BjÖrkman, 1998. Potential and existing uses of Trichoderma and Gliocladium for plant disease control and plant growth enhancement. In: Harman, G.E., Kubicek, C.P. (Eds.), Trichoderma and Gliocladium, Vol. 2. Taylor \& Francis, London, United Kingdom, 229-265.

Hoftman, E. (1967) Chromatography. $2^{\text {nd }}$ ed., Reinhold Publ. Corp. 208515.

Jackson, M.L. (1973). Soil Chemical Analysis. Prentice-Hall -of India private, New Delhi, India.

Kaledin V.I, Pakharukova M.Y, Pinovarova E.N, Kropachev K.Y, Baginskaya NV, Vasilieva ED, Ilnitskaya SI, Nikitenko E.V, Kobzev V.F, Merkulova TI (2009). Correlation between hepatocarcinogenic effect of estragole and its influence on glucocorticoid induction of liver-specific enzymes and activities of FOXA and HNF4 transcription factors in mouse and rat liver. Biochemistry (Moscow) 74: 377-384. 
Kloepper, J. W., and Schroth, M. N., 1978. Plant growth-promoting rhizobacteria on radishes in: Proceedings of the 4th International Conference on Plant Pathogenic Bacteria. 2. Station de Pathologie Végétale et de Phytobactériologie, INRA, Angers, France, 879- 882.

Kloepper, J. W., and Schroth, M. N., 1981, Development of powder formulation of rhizobacteria for inoculation of potato seed pieces. Phytopathology, 71: 590-592.

Kosekia, P.M., A.L. Villavicencioa and M.S. Britoa, 2002. Effects of irradiation in medicinal and eatable herbs. Radiat Phys Chem., 63: 681- 684.

Lifshutz, R.; J.W. Kloepper and M. Kozolowski (1987). Growth promotion of canola (rapeseed) seedlings by a strain of Pseudomonas putida under genobiotics conditions. Can. J. Microbial, 33:390-395.

Little , T.M and F. J. Hills (1978) : Agricultural Experimentation - Design and Analysis . John Wiley and Sons, Inc.,53- 60

Mayak, S., T. Tirosh, and B.R. Glick, 2004a. Plant growth-promoting bacteria that confer resistance to water stress in tomatoes and pepper. Plant Sci. 166, 525-530.

Mayak, S., T. Tirosh, and B.R. Glick, 2004b. Plant growth-promoting bacteria confer resistance in tomato plants to salt stress. Plant Physiol. Biochem. 42, 565- 572.

McIntosh, Charles, 1853. The Book of the Garden. Edinburgh and London: W. Blackwood, 237. 7.

Michel, K.A., J.K. Gilles, R.P.A. Ramilton and F. Smith, 1956.

Colourimetric method for determination of sugars and related substances. Anal.Chem., 28: 3.

Moharram, T.M.M.; M.S.A. Safwat; M.M. Farghaly and M.Z. Ali, (1997). Effect of inoculation with Bacillus polymyxa on growth and nitrogen fixation of wheat under graded levels of inorganic and organic nitrogen. Egypt. J. of Microbial., 32 (1): 1-15.

Nielson P. and Sorenson J. (1997) Multi-target and medium independent fungal antagonism by hydrolytic enzymes in Paenibacillus polymyxa and Bacillus pumilus strains from barley rhizosphere. FEMS Microbiol Ecol., 22:183-192

Noel, T.C., C. Sheng, C.K. Yost, R.P. Pharis and M.F. Hynes, 1996. Rhizobium leguminosarum as a plant growth promoting rhizobacterium: direct growth promotion of canola and lettuce. Can. J. Microbiol., 42: 279-283. 
Nurzyńska-Wierdak, R; Borowski1，B.; Dzida，K.; Zawiślak1，G.; Kowalski, R. (2013). Essential oil composition of sweet basil cultivars as affected by nitrogen and potassium fertilization. Turk. $J$. Agric. For., 37: 427-436

Okunishi,S,; K. Sako; H. Mano; A. Imamura and H. Mofisaki(2005). Bacterial flora of endophytes in the maturing seed of cultivated rice (Oryza sativa). Microb. Environ., 20:168-177.

Ordookhani, K., K. Khavazi, A. Moezzi and F. Rejali, 2010. Influence of PGPR and AMF on antioxidant activity, lycopene and potassium contents in tomato. African Journal of Agricultural Research, 5 (10): 1108-1116.

Phippen, W.B. and J.E. Simon, 1998. Anthocyanins in basil (Ocimum basilicum L.). J . Agric. Food Chem., 46: 1734-1738.

Politeo, O., M. Jukic and M. Milos, 2007. Chemical composition and antioxidant capacity of free volatile aglycones from basil (Ocimum basilicum L.) compared with its essential oil. Food Chemistry, 101: 379-385.

Ramadan, Heba E.; M.A. Ali; Heba Shehata; M. El-Kattan and M. Fayez. (2007). Diazotroph-bioagent-Pathogen panorama towards the production of environmentally safe cucumber. J. Agric. Sci. Mansoura Univ., 32 (5): 3963-3709.

Rosado AS, and Seldin L (1993). Production of potentially novel antimicrobial substance by Bacillus polymyxa. World J Microbiol Biotechnol 9:521-528

Sajjadi, S.E., 2006. Analysis of the essential oils of two cultivated basil (Ocimum basilicum L.) from Iran. Daru, 14(3): 128-130.

Shishido M, Breuil C, and Christopher PC (1999). Endophytic colonization of spruce by plant growth promoting rhizobacteria. FEMS Microbiol. Ecol., 29:191-196

Sifola, M.I. and Barbieri, G. (2006). Growth, yield, and essential oil content of three cultivars of basil grown under different levels of nitrogen in the field. Sci. Hort., 108: 408-413.

Simon, J.E., J., Quinn, R.G., Murray and Basil (1990) source of essential oils. In Advances in new crops; Janick, J., Simon, J. E., Eds.; Timber Press: Portland, OR; 484-489.

Soudi, Amal K.M.; Sama E. H. Omran and Kh. A. Aboushady (2008). The response of sugar beet to nitrogen and phosphor mineral and partial biofertilization using some micronutrients foliar application. Egypt. J. Appl. Sci. , 23 (4-B): 502-516. 
Sudha SN, Jayakumar R, and Sekar V (1999). Introduction and expression of the cry1Ac gene of Bacillus thuringiensis in a cereal-associated bacterium, Bacillus polymyxa . Curr Microbiol, 38:163-167.

Thalmann, A. (1967). Uber die microbiella aktivitat undihr benziehungzu frucht-bat kettes markmalen einiger acherboden unter besonderer beruksi chtigung der Dehydrogenase aktivitat (TTC. Reduktion). Biss, Gieben. Ph.D. Thesis, W. Germany.

Timmusk S, Nicander B, Granhall U, Tillberg E (1999). Cytokinin production by Paenibacillus polymyxa. Soil Biol Biochem 31:18471852

Udagwa, K. and S. Kinosheta (1961). A colorimetric determination of gibberellic acid. J. Agric. Chem. Soc., Japan., 35: 219-223.

Umerie, S.C., H.U. Anaso and L.J.C. Anyasoro, 1998. Insecticidal potentials of Ocimum basilicum leaf-extract. Bioresourch Technol., 64: 237-239.

Whitelaw M. A.; T. A. Hardenand and G. L. Bender (1997) Plant growth promotion of wheat inoculated with Penicillium radicum sp. Nov, Aust. J. Soil Res., 35: 291-300

.Yamaguchi , M. and A.P. Minges (1956). Brown checking of celery, assumption of boron deficiency. I: Field observations. Variety Susceptibility and Chemical Analysis.

Zaghloul, R.A.; Hanafy, Ehsan, A.; Neweigy, N.A. and Khalifa, Neamat, A. (2007). Application of biofertilization and biological control for tomato production. Proceedings of $12^{\text {th }}$ Microbiology Conf., Cairo, Egypt.

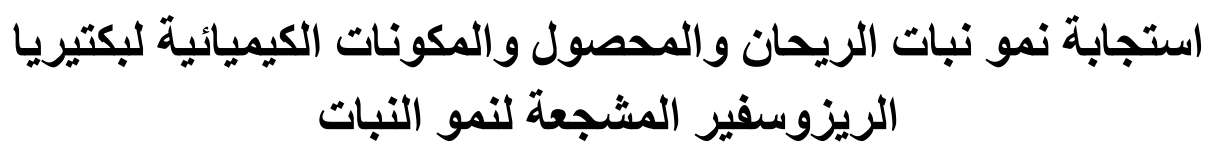

$$
\begin{aligned}
& \text { عبيز حمدي قاسم *مدحت يماتي أبوزيد**، وهبه شحاتة شحاتة }
\end{aligned}
$$

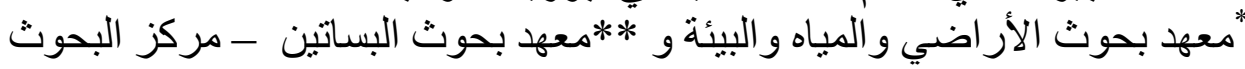

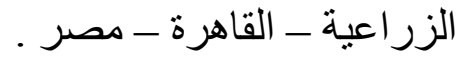

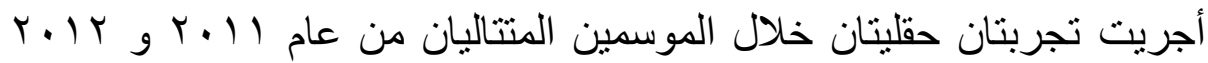

لدراسة تأثثير التلقيح ببعض سلان الات بكتيريا الريزوسفير المشجعة لنمو النبات

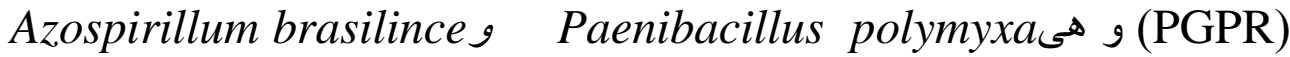


وبعض عاز لات من الـ Pseudomonas sp , Bacillus subtilis تحت تركيز

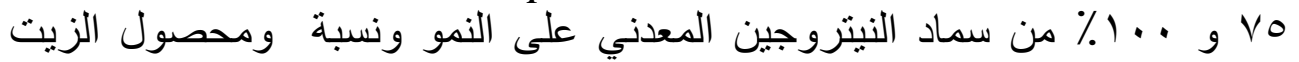

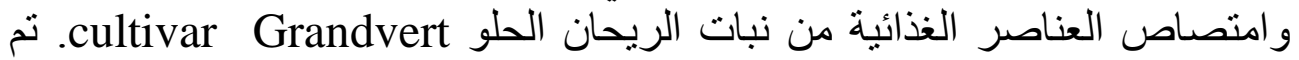

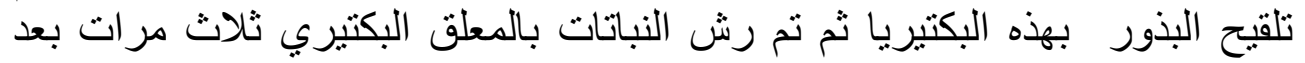

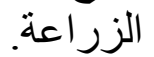

أنشارت النتائج أن التلقيح مع هذه PGPR تسبب زيادة كبيرة في طول النبات،

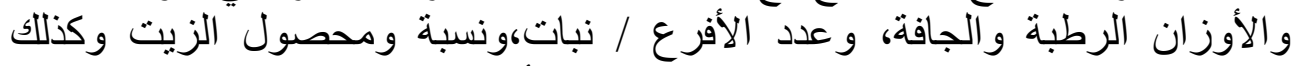

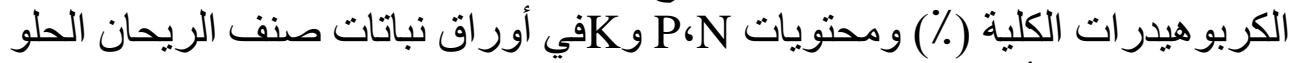

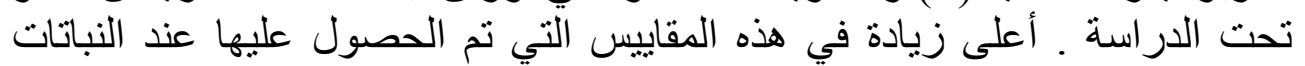

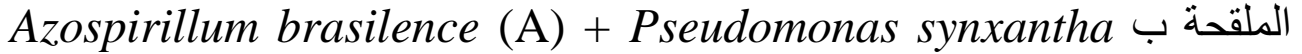
(P1) + Bacillus subtilis 2 (B2

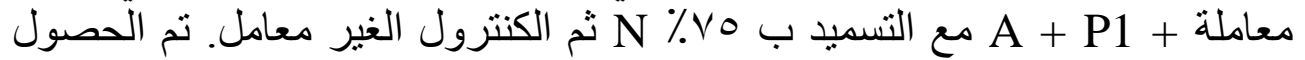

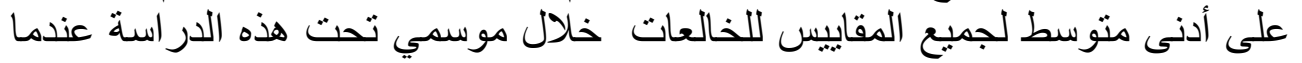

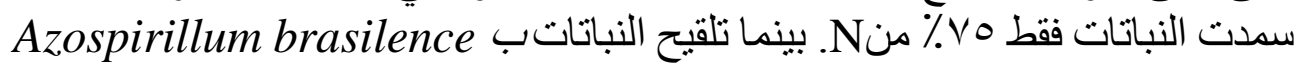
فى Pseudomonas synxantha.(P1) + Bacillus subtilis (B2) (A) +

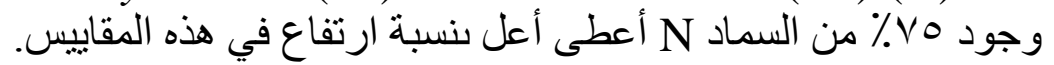

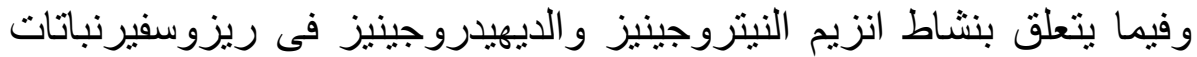
الريحان، تثير النتائج إل أن التلقيح مع هذه

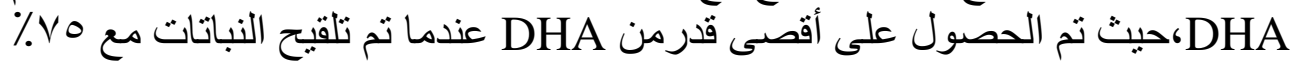

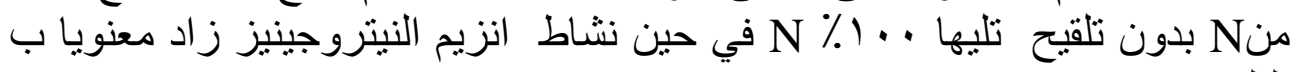

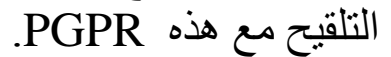
وبالنسبة لككونات الزيت الأساسية (\%) أظهرت البيانات ان مكون اللينالول (Linalool)

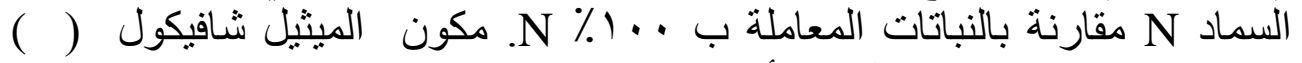
Methyl chavicol

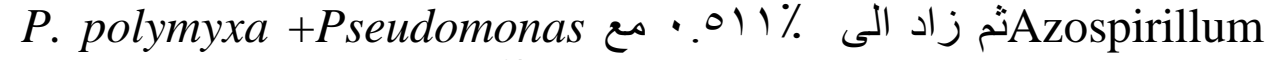
synxantha + Bacillus subtilis 2

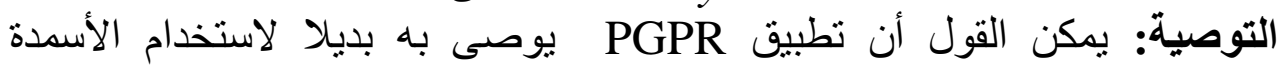

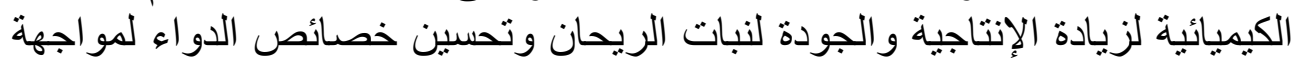
الاستهلاك المحلي و التصدير. 